\title{
Defining Science From Multicultural And Universal Perspectives: A Review Of Research And Its Implications For Science Education In Africa
}

\author{
Ayodele O.Ogunleye, University of Lagos, Nigeria
}

\begin{abstract}
The current move toward "science for all" in all parts of the globe necessitates that consideration be given to how pupils move between their everyday life and the world of school science, how pupils deal with cognitive conflicts between those two worlds, and what this means for effective teaching of science. In recent times, multiculturalism's proper place in science education has been the subject of considerable controversy in science education literature. The key issue has been whether a multicultural approach to science education is compatible with a universalistic conception of science. The purpose of this paper is to examine the scope of multicultural education and to review the definition of science put forward from multicultural perspectives in contrast to a universalistic perspective on science; i.e. the standard account and the various propositions put forward for both universal and indigenous science. The paper then offers suggestions as to the implications for teaching science in the African context by encouraging science teachers to incorporate examples of African science into their lessons and also teach children to have equal respect for the accomplishments of all cultures, such that they realize that science is a part of every culture worldwide.
\end{abstract}

Keywords: Multicultural Science Education, Universalistic Perspective of Science, Indigenous Science, Cultural Pluralism, Acculturation, Teaching/Learning Science, African Science, Boarder Crossing Theory, Collateral Learning Theory, Contiguity Learning Hypothesis.

\section{INTRODUCTION}

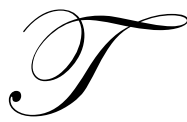

he concept of multicultural education is relatively new, although the phenomenon is not new. Multicultural education originated in the United States in the 1990's when the people of the United States were forced to re-examine their cultural heritage in order to address the educational needs of a society that continues to struggle with the overt and covert national conflict about race, ethnicity, social class, and gender as a result of the imbalance of power between the dominant culture and other subjugated cultures. The need to address the various learning needs of such a diverse student population, and the subsequent pluralistic society for which those children will be responsible, therefore became an urgent task faced by the American people. The debate on the discourse and practice of multicultural education therefore has been an effort to mine the possibilities of plurality through education. Inherent in this relatively new cultural pluralism is the respect for all ethnic, religious and social class backgrounds.

Today, multicultural education means different things to different people, even though the differences are not as great, confusing, or contradictory. Some definitions rely on the cultural characteristics of diverse groups, while others emphasize social problems (particularly those associated with oppression), political power, and the reallocation of economic resources. Some restrict their focus to people of colour, while others include all major groups that are different in any way from mainstream Americans. Other definitions limit multicultural education to characteristics of local schools, and still others provide directions for school reform in all settings regardless of their 
characteristics. It should be noted that many of these differences are more semantic than substantive and can be regarded as reflections of the developmental level in the field of multicultural education and also the disciplinary orientation of its advocates. However, despite all the variations in the definition, all conceptions of multicultural education (according to Gay, 1994) share the following four characteristics:

1. They are based upon a common set of assumptions.

2. They evolve out of common concerns.

3. They contain common guidelines for action.

4. They share a desire to make cultural pluralism and ethnic diversity integral parts of the educational process. education:

Gay (1994) further listed the following as some of the most frequently used definitions of multicultural

1. Comprehensive school reform and basic education for all students that challenges all forms of discrimination, permeates instruction and interpersonal relations in the classroom, and advances the democratic principles of social justice (Nieto, 1992).

2. Institutionalizing a philosophy of cultural pluralism within the educational system that is grounded in principles of equality, mutual respect, acceptance and understanding, and moral commitment to social justice (Baptiste, 1979).

3. An education free of inherited biases, with freedom to explore other perspectives and cultures, inspired by the goal of making children sensitive to the plurality of the ways of life, different modes of analyzing experiences and ideas, and ways of looking at history found throughout the world (Parekh, 1986, pp. 2627).

4. An approach to teaching and learning based upon democratic values that foster cultural pluralism; in its most comprehensive form, it is a commitment to achieving educational equality, developing curricula that builds understanding about ethnic groups, and combating oppressive practices (Bennett, 1990).

5. A type of education that is concerned with various groups in American society that are victims of discrimination and assaults because of their unique cultural characteristics (ethnic, racial, linguistic, gender, etc.); it includes studying such key concepts as prejudice, identity, conflicts, and alienation, and modifying school practices and policies to reflect an appreciation for ethnic diversity in the United States (Banks, 1997).

From these definitions, one could remark that multicultural education is a model of an educational reform movement, which is intended to change the structure of educational institutions and all components of the educational enterprise, including its underlying values, procedural rules, curricula, instructional materials, organizational structure, and governance policies so as to reflect cultural pluralism of the society in other that all students have an equal chance to achieve academic success. According to Massey (1991), a multicultural society is one where there is a legitimately accepted diversity of cultural appurtenances based on such dimensions as race, colour, language, creed, sex, class, religion, etc. and is committed to the basic ethics of "respect for persons" against racism and sexism.

Some of the advocates of multicultural education agree that the content of multicultural education programs should include culture, ethnicity, diversity, racism, cultural pluralism, acculturation, enculturation, unequal distribution of resources and opportunities, and other socio-political problems stemming from long histories of oppression. They are also of the opinion that, at best, multicultural education is a philosophy, a methodology for educational reform, and a set of specific content areas within instructional programs.

\section{THE MULTICULTURAL CONTEXT}

Several science educators have offered various definitions for some important key words, such as culture, ethnicity, diversity, racism, cultural pluralism, acculturation and enculturation, often used in the multicultural context. According to Banks (1999:115), culture, for example, simply means ideation, symbols, behaviours, values, and beliefs that are shaped by a human group, including institutions or other components of human societies that are created by human groups to meet their survival needs while Bernnet (1986:8) perceived culture as that human-made part of the environment that satisfies all basic needs for survival and adaptation to the environment. There is also the 
concept of sub-culture which, according to Aikenhead (1996), consists of school culture, classroom culture, gay culture, adolescent culture, science culture, and class culture.

Ethnicity, according to Banks (1999:115), denotes a common history, a sense of people hood and identity, values, behavioural characteristics and communication, all of which are shared by a group called an ethnic group whose members usually view their group as distinct and separate from other cultural groups within a society.

Diversity is a term that relates to a multifaceted perspective on culture. According to Arvisu (1994:76), diversity means the recognition of variation among people related to their cultural heritages, racial and ethnic identities, and gender and class experiences. On the other hand, racism refers to the term race, which connotes biological differences amongst people. Bernett (1990:43) defines race as an erroneous concept used to divide humankind into broad categories on the basis of physical or biological characteristics, such as colour of skin.

Bernett (1986:37) defined cultural pluralism as a process of compromise characterised by a reciprocal or mutual understanding and respect between two or more cultural groups. Thus, cultural pluralism advances the principles of cultural preservation (i.e. it retains one's core cultural ways) and cultural integration (i.e. it adapts other cultures to enrich one's culture).

Acculturation, according to Ovando \& Collier (1998:144), is a process by which one cultural group takes on and incorporates one or more cultural traits of another group, thereby resulting in new or blended cultural patterns. Sometimes this can also result to a loss of acculturated core cultural ways. On the other hand, Ovando \& Collier (1998:138) believed that to every culture is the process of enculturation, which is a cultural generation-togeneration educative process (i.e. the actual process of learning norms, beliefs, language, etc. as it takes place in specific cultures and in which a particular group transmits cultural patterns to succeeding generations.

\section{GOALS OF MULTICULTURAL EDUCATION}

The goals of multicultural education are to offer students an equal opportunity to learn and see the possibilities awaiting them in life. While specific goals and related objectives are quite numerous, and vary according to contextual factors, such as school settings, audiences, timing, purposes, and perspectives, many of such goals fall into seven general clusters which cover all three domains of learning (cognitive, affective, and psychomotor) and also incorporate both the intrinsic (ends) and instrumental (means) values of multicultural education. These goals cluster around ethnic and cultural literacy, personal development, attitude, and value, which, according to Gay (1994), include the following:

1. Developing ethnic and cultural literacy by providing students with information about the history and contributions of ethnic groups who traditionally have been excluded from instructional materials and curricula; and secondly, to replace the distorted and biased images of those groups that were included in the curricula with more accurate and significant information. This is because many students still know too little about the history, heritage, culture, and contributions of groups in their society.

2. Personal development by assisting students to develop greater self-understanding, positive self-concepts, and pride in one's ethnic identity all contribute to the overall intellectual, academic, and social achievement of students. Students who feel good about themselves are likely to be more open and receptive to interaction with others and to respect their cultures and identities.

3. Promoting attitudes and value clarification stems from the principles of human dignity, justice, equality, freedom, self-determination, and democracy. The intent is to teach youths to respect and embrace ethnic pluralism, to realize that cultural differences are not synonymous with deficiencies or inferiorities, and to recognize that diversity is an integral part of the human condition.

4. Promoting multicultural social competence by teaching students how to interact with and understand people who are ethnically, racially, and culturally different from themselves, understanding alternative points of view and frames of reference, and analyzing how cultural conditions affect values, attitudes, beliefs, preferences, expectations, and behaviours. 
5. Promoting basic skill proficiency through the teaching and learning of basic literacy skills of ethnically different students. Multicultural education can improve mastery of reading, writing, and mathematical skills, subject matter content, and intellectual process skills, such as problem-solving, critical thinking, and conflict resolution by providing content and techniques that are more meaningful to the lives and frame of reference of ethnically different students. Using ethnic materials, experiences, and examples as the contexts for teaching, practicing, and demonstrating mastery of academic and subject matter skills increases the appeal of the tools of instruction, heightens the practical relevance of the skills to be learned, and improves students' time on tasks.

6. Promoting educational equity and excellence by building upon the idea that comparability, instead of sameness, is the key to providing equitable educational opportunities for ethnically different students. In order to determine what constitutes comparability of learning opportunities, educators must thoroughly understand how culture shapes learning styles, teaching behaviours, and educational decisions. They must then develop a variety of means to accomplish common learning outcomes that reflect the preferences and styles of a wide variety of groups and individuals.

7. Promoting personal empowerment for social reform by cultivating, in students, attitudes, values, habits, and skills so that they can become social change agents who are committed to reforming society in order to eradicate ethnic and racial disparities in opportunities and improving their knowledge of ethnic issues, as well as develop decision-making abilities, social action skills, leadership capabilities, a sense of political efficacy, and a moral commitment to human dignity and equality.

Given the context of the development of the field of multicultural education and education research in general, it would be interesting to provide a review of the meaning of science in both the universalistic and multicultural perspectives with a focus on research looking at the differences between the two perspectives.

\section{THE UNIVERSALISTIC PERSPECTIVES OF SCIENCE (I.E. WESTERN MODERN SCIENCE)}

Is science universal? This question has often been a subject of concern to proponents of multicultural perspectives on science. In the tradition of science, as practiced in the West for the past 200 years or more, and also in the tradition of school science, the answer is, "Yes, science is universal". According to the literature, there is a pragmatic view to science broadly acceptable in the scientific community and described in accounts by scientists themselves. In addition, science educators (Driver, Leach, Millar \& Scott, 1996; and Cobern, 1991 \& 1995) who thoughtfully examined the range of philosophical, historical and sociological views of science, were also able to arrive at critical areas of consensus which were helpful, given the following, as what is understood to be the definition of the Standard Account of science (or Western Science):

1. Science is a naturalistic, material explanatory system used to account for natural phenomena that ideally must be objectively and empirically testable.

2. Science is about natural phenomena. It is not about the things that humans construct, such as economic systems; nor is it about spiritual phenomena.

3. The explanations that science offers are naturalistic and material. It follows, therefore, that scientific explanations are not about the spiritual, emotional, economic, aesthetic, and social aspects of human experience.

4. Science explanations are empirically testable (at least in principle) against natural phenomena (the test for empirical consistency) or against other scientific explanations of natural phenomena (the test for theoretical consistency). Science involves collecting data (i.e. evidence) and a scientific explanation must be able to account for this data.

5. Scientific testing strives to be objective. In recent years, this value in science has been derided as "objectivism... a universal, value-free process".

6. Science is an explanatory system; it is more than a descriptive ad hoc accounting of natural phenomena. Science seeks to parsimoniously explain how things work invoking only natural causes, and these explanations are woven into a system of theoretical thought. Theories, however, are typically underdetermined; that is, they go beyond the available data and are therefore conjectural. 
This Standard Account of science can be called Western Science given its historic origins in Ancient Greek and European culture. Speculative thought about nature, natural philosophy, and later what became known simply as science, have always been engaged and practiced with Western culture. This Western experience with science has been a long one and, in a sense, they have matured sufficiently.

According to Stanley and Brickhouse (1994, pp. 36-37), the following propositions are true of the universalistic definition of science:

1. Universalism claims that reality is what it is, irrespective of what humans think or know about it."

2. Universalism assumes that reality is ordered. "Reality has a structure that is universal and invariant across time and place."

3. Universalism believes that reality is knowable and WMS has provided the most effective and reliable way to discover knowledge about the natural world.

4. Universalism believes that Western science somehow enjoys "unmediated access" to reality.

5. Universalism believed that culture does not influence the truth claim of science.

Poole (1995) is of the view that many efforts have been made to place science in a Western cultural context, and the science curricula of many countries of the world have drawn on this traditional emphasis and accepted the view that good science implies Western science; also that it is the only science worth learning or teaching. Moreover, it is argued that traditional sciences are a mixture of experience and superstition and do not satisfy the rigour of 'good science' (Reiss, 1993).

The point being made here is that the West judged the rest of the world by its own measure of choice, Western science and Western technology, and used education to enforce change on those societies found deficient. According to Adams (1989, p. 4), European "perceptions of the material superiority of their own cultures, particularly as manifested in scientific thought and technological innovation, shaped their attitudes toward and interaction with peoples they encountered overseas". Furthermore, it was believed that since Europe itself was an expansionist culture; hence, European exploration, conquest and colonization of lands beyond Europe brought Western science to those lands and their inhabitants. In these parts of the world where Western science is experienced as a relatively new phenomena, the interaction of science 'with culture' has taken a more violent form and the disintegrating effects have been much more sharply experienced" (Ladrière, 1977, p. 14). Western scientists did have scientific interests in the rest of the world, and many areas of the globe became field sites for the practice of Western science by Western scientists (Basalla, 1967).

\section{THE MULTICULTURAL PERSPECTIVES OF SCIENCE (ALTERNATIVE CONCEPTIONS OF SCIENCE)}

Alternative conceptions of the world do exist, and many cultures have constructed pseudo-scientific and mythical explanations of the world. Hodson (1992) argues that the history of medicine, astronomy and technology, particularly rich in exemplars of major contributions by Islamic, Indian and Chinese scientists and technologists, help to promote awareness that current scientific ideas are not derived solely from post-Renaissance Western societies. Mattews (1994) endorses this view when he remarked that there are a number of equally valid and equally good sciences, and that both Western and ethnic sciences should be accorded the same status in schools.

When scientists occasionally took note of indigenous knowledge of nature, that knowledge was distinctively labelled ethno-science and never simply science. This is not to say that such indigenous science was regarded as without value. However, according to Linden (1991), there has been a long tradition of Western science finding value in indigenous knowledge, especially as an aid to pharmaceutical discovery. But finding value in indigenous knowledge is not the same as conferring the title, science, and admitting indigenous knowledge of Nature to the Standard Account.

In recent times, however, multicultural perspectives of science has become an increasingly rich area of study as science educators struggle to find answers to the question of "what is science" and how to teach it in multicultural settings. According to Bullivant (1981), culture can be thought of as the knowledge and conceptions embodied in symbolic and non-symbolic communication modes, about the technology and skills, customary 
behaviours, values, beliefs and attitudes, through which a society has evolved from its historical past and progressively modifies and augments to give meaning to and cope with the process and anticipated future problems of its existence (1981, p.19).

If science is conceptualized in this way, then it constitutes a separate culture. In general, debates in science education initially focused on the belief as to whether scientific knowledge has a universal essence (Mathew, 1995; Gross and Lavitt, 1994) as opposed to multiculturalism; that is, scientific knowledge does not have a universal essence because Western Modern Science (WMS) only serves as a politics of exclusion and suppresses the fact that there are other forms of science which can sit the purposes of good life and can also function as a stepping stone for multicultural students of science (Hodson,1993; Siegel,1997; Jegede,1996; Ogawa,1995).

Siegel (2002, p.804) put forward the following argument that the reliable and effective knowledge of the world, provided by Western Modern Science, is the same as that reality provided by indigenous science. He was of the opinion that Universalists are committed to realism only in the sense that there is a world that exits independently of our thoughts about it. According to him, there is nothing concerning the "ordering of reality" that characterizes universalism, other than the WMS commitment to it. Even though WMS has provided the most effective and reliable way to discover knowledge about the natural world, "ethnic science" is equally more effective and reliable to produce such type of knowledge.

Much of the multicultural literature on science seems to be saying that the problem with the Standard Account is that it is taken to be the only account of science. It is an exclusive and universally appropriate account. Kawagley et al (1998, p. 134) argued that "such a narrow view of science not only diminishes the legitimacy of knowledge derived through generations of naturalistic observation and insight, it simultaneously devalues those cultures which traditionally rely heavily on naturalistic observation and insight."

Atwater and Riley (1993) tell us "a body of knowledge about multicultural science education does exist, even though it may be scanty" (1993, p. 665). If we are looking forward in this "state of the art" exercise, then perhaps we could start by collecting together of this body of knowledge, which in no way was scanty.

According to Atwater (1996:821), multicultural science education aims at providing equitable opportunities that include an understanding of realities constructed by individuals from various cultural groups and how these realities can be reconstituted to include scientific reality. Cummins 1986 (in Atwater 1996: 831) identified four areas for empowering multicultural science as follows:

1. Incorporation of students' culture and language in teaching of science.

2. Collaborative participation of the community in schools and science classrooms.

3. Orientation of science pedagogy toward reciprocal interaction.

4. Advocacy rather than legitimacy of failure as a goal for science assessment.

According to Krugly-Smolrka (2001), multicultural science education deals with at least three very different contexts: western science education occurring in non-western cultural context, western science education in a western context, but with populations of predominantly non-western origin (for example, aboriginal populations), and western science education in a western context, but with populations of varied cultural origin, both western and non-western. It is possible that in the three contexts, different aspects of culture will have greater salience. Any useful theory of the role of culture in science education would, however, be applicable to all three as is; for example, the concept of crossing borders between cultures (Aikenhead, 1996).

Some science educators further argued on how real is the bone of contention among multiculturalists? Is it the alleged universality of science, or is it the intellectual exclusiveness of science according to the Standard Account? This is because the post-colonialist arguments rejecting the universality of science seem to be arguments more about the exclusivity of science. Hence, even if the definition of science were broadened to include what is now excluded, one would still have a "universal" science. Hence, the real difficulty that multiculturalists have with the Standard Account is not its claim to universality, but its exclusiveness. 
However, according to Kawagley, et al (1998, p. 134) on the relationship between the Standard Account and indigenous knowledge, emphasized that:

Such a narrow view of science not only diminishes the legitimacy of knowledge derived through generations of naturalistic observation and insight, it simultaneously devalues those cultures which traditionally rely heavily on naturalistic observation and insight.

He was of the belief that no single origin for science exists and that science has a plurality of origins and a plurality of practices. Science from this perspective refers to descriptive knowledge of nature developed through experience with nature. The definition of science used here is consistent with Ogawa (1995, p.588) who refers to science simply as "a rational perceiving of reality".

However, starting in the 1990s, non-Western peoples and some scholars within the West began to formally and overtly resist this imperial Western attitude toward indigenous knowledge of Nature. New epistemological perspectives, such as multiculturalism (Stanley \& Brickhouse, 1994), post colonialism (McKinley, 1997), and post modernism (Lyotard, 1995), rose to challenge the conventional Western wisdom on the relationship between science and culture and the Standard Account itself.

Linn \& Burbules, (1993) also argued that social constructivism, which characterizes the nature of knowledge, consists of the following: (1) knowledge is not a passive commodity to be transferred from a teacher to learners, (2) pupils cannot - and should not - be made to absorb knowledge in a spongy fashion, (3) knowledge cannot exist separate from the knower, (4) learning is a social process mediated by the learner's environment, and (5) the prior or indigenous knowledge of the learner is of significance in accomplishing the construction of meaning in a new situation. Hence, according to them, all learning is mediated by culture and takes place in a social context. The role of the social context is to scaffold the learner and provide hints and help that foster co-construction of knowledge, while interacting with other members of the society culture.

Ezeabasili (1977, p. xi) states that African science is "African account of nature and how it works." He goes on to say that "...the black African has an authentic scientific culture." According to Ezeabasili (p. xviii), African science and Western science both have their uses and misuses. There is overlap between the two and they are not mutually exclusive. The major problem lies with the denial by Western science of the validity of Africa's contributions. Because every culture's way of viewing the world is different, it seems probable that every culture may have developed unique strategies for doing science.

Ogunniyi (1988) compared the traditional world view with that of Western science and concluded that the African concept of causality, chance and/or probability is based upon a different logic from that of science." The belief in the laws of cause and effect is very strong in Western culture, but the rest of the world throughout the centuries has never bothered about these laws; the same cause can have different effects; effects may be mistaken for causes; and finally, the mere fact of being posterior in time does not make a thing an effect. Oginniyi also feels that Western science is more concerned with things; i.e. inanimate objects, while African science places more emphasis on people. According to Ogunniyi (p. 4), there are four important myths that surround Western science:

1. Success is the result of rationalism and empiricism.

2. Objectivity exists in science.

3. There is only one way of "coping with experience".

4. A "mechanistic view of the world" provides an accurate explanation of the way the world works.

Science in Ivan Van Sertima's (1984) book "Blacks in Science: Ancient and Modern" cited countless examples of African science from articles by several different authors.

Furthermore, Margaret Alic (1986), in her book "Hypatia's Heritage", discussed women in science. She asserted that women were the first botanists and she attributed the following accomplishments to the women of pre-history, many of whom were undoubtedly African:

1. Methods of gathering, preparing and preserving food 
2. Construction of devices to carry food and infants

3. Sticks, levers, hand axes for digging and processing plants

4. Invented the mortar and pestle. Alic (1986, p. 13) states that "The tools developed by prehistoric women are still in evidence in modern-day chemistry laboratories."

5. Butchering of animals, tanning of hides

6. Production of needles, use of dyes

7. Drying, storage of herbs for use as medicines

8. Discovery of the uses of plants through trial and error and experimentation

Alic (1986, p. 15) bases her claims on the assumption that "...evidence from the early scientific work of women can be traced..." from "oral traditions." Alic (1986, p. 15) goes on to say that Neolithic women were often thought to be possessed of magical powers, not only because of their ability to give birth, but also because of their skills in the domestic sciences - manufacturing, pottery, agriculture, the domestication of animals and healing. It was these achievements that early cultures personified in their goddesses.

To learn science, according to Wolcott (1991), is to acquire the culture of science; and for pupils to acquire the culture of science, they must travel from their everyday life to the world of science found in their science classroom. The western science taught in schools is often shown to be more superior to knowledge within the local culture.

\section{SOME THEORETICAL CONSTRUCTS}

Different cultural processes are involved in the acquisition of science culture. These cultural clashes between pupils' lives and the world of Western science can create hazards for many pupils, which they must deal with to learn science effectively and meaningfully. In response to such hazards, pupils understandably invent ways to avoid constructing scientific ("foreign") knowledge, or pupils conveniently store the constructed scientific knowledge in their minds out of harms way from interfering with their life experiences. The cultural clashes between pupils' lives and the world of Western science present a challenge to science educators. These clashes create a major obstacle to many reform movements around the world that have taken on a science-for-all ideology. Specifically, it makes science teaching a Herculean task and the meaningful learning of science an ordeal for many pupils.

Some science educators have proposed, in recent times, some theories/hypotheses which emanate from the worldview theory and which can be used to further explain how students from different cultures move from their everyday lives and the world of science and how they are able to deal with the cognitive conflicts arising from the two worlds. There are presently three such theories: Border Crossing, the Collateral Learning Theory, and the Contiguity Learning Hypothesis. The various explanations are as follows:

\section{THE BORDER CROSSING THEORY}

This theory, proposed by Aikenhead (1996), viewed students' experiences with school science in the form of students "crossing borders" from the subcultures of their socio-economic environments into the subcultures of science. In other to do so, he distinguished between four types of border crossing; namely:

1. Smooth border crossing, which occurs when students' world views are congruent with school science.

2. Managed border crossing, which occurs when students' world views are different from the science world views; hence, such transition is regarded as managed.

3. Hazardous border crossing, which occurs when students' world views and their science world views are somehow diffused with each other, leading to a hazardous transition.

4. Impossible border crossing, which occurs when students' world views and their science world views are incompatible with each other. 


\section{THE COLLATERAL LEARNING THEORY}

This theory, proposed by Jegede (1995), is a mechanism that can be used to explain how students' could harmonize the conflict arising from their traditional world views and their science world views. To Jegede, effective cultural border crossing is indeed a complex event. The phenomenon to which collateral learning refers is universal and well-known worldwide. Collateral learning generally involves two or more conflicting schemata held simultaneously in long-term memory. Jegede $(1995,1996$, and 1997) recognized variations in the degree to which the conflicting ideas interact with each other and the degree to which conflicts are resolved. Collateral learning theory postulates a spectrum of cognitive experiences (parallel, simultaneous, dependent, and secured collateral learning) to explain cultural border crossings. These four types of collateral learning are not separate categories, but points along a spectrum depicting degrees of conflict/resolution.

At one extreme of collateral learning, the conflicting schemata do not interact at all. This is parallel collateral learning. In such a situation, students could access one schema or the other, depending on the context. For example, students can use a scientific concept of energy only in school, but never in their everyday world where common sense concepts of energy prevail. This segregation of school science content within the minds of pupils was called "cognitive apartheid" by Cobern (1996).

At the opposite extreme of collateral learning, conflicting schemata consciously interact and the conflict is resolved in some manner. This is called secured collateral learning. The student will have developed a satisfactory reason for holding onto both schemata, even though the schemata may appear to conflict, or else the student will have achieved a convergence toward commonality by one schema reinforcing the other, resulting in a new conception in long-term memory.

Between these two extremes of parallel and secured collateral learning, we find varying degrees and types of interaction between conflicting schemata and various forms of conflict resolution. In the dependent collateral learning, the schema from one world view or domain of knowledge challenges another from a different world view or domain of knowledge, to such an extent that permits the student to modify an existing schema without radically restructuring the existing world view or domain of knowledge. For many pupils, learning science in order to imbibe its culture meaningfully, often involves cognitive conflicts of some kind. Therefore, meaningful learning often results in parallel, dependent, or secured collateral learning.

Simultaneous collateral learning, which is the fourth one, is a situation in which learning a concept in one domain of knowledge or culture can facilitate the learning of a similar or related concept in another milieu. Depending on the knowledge base of the learner, a number of interacting elements, such as current problem state, problem solving techniques, and differences or similarities between the ideas from two different world views, are simultaneously assessed. For a student who needs to move into the culture of science, he requires an effective use of collateral learning with a heavy reliance on successful cultural border crossings into school science. This is the point where Aikenhead \& Jegede (1999) have argued that both collateral and border crossing are fundamentally interrelated because effective collateral learning in science classrooms will rely on successful cultural border crossing into school science.

\section{THE CONTIGUITY LEARNING HYPOTHESIS}

This hypothesis was proposed by Ogunniyi (2002) as an explanatory model for cognitive boarder crossing, which he believed is a dynamic process rather than a static one. The hypothesis proposes that border crossing depends, to a very great extent, on the context and interest being served. Hence, whether a border crossing is collateral or multilateral will depend on such factors as:

1. The consequences of a given response

2. The interest or satisfaction derived from a learning experience

3. The desire to gain mastery over a learning task or the challenge of meeting peer, teacher, parent, or societal expectations, etc. 
The hypothesis makes use of psychological, physiological and philosophical explanations to explicate the process of border crossing, especially from three basic world view schemata of the learner. These are from the learners' traditional beliefs, common sense, intuitive knowledge, and his knowledge of science - all of which are derived from his culture, school and life worlds as a whole.

The capacity to think differently in diverse cultures (everyday and science cultures, for instance) and the capacity to resolve conflicting beliefs between those cultures, are familiar human traits. However, these capacities are not equally shared among all people, as anthropologists Phelan et al (1991) discovered when they investigated pupils' movement between the worlds (subcultures) of families, peer groups, school, and classrooms.

Therefore, it is often important and useful for educators in different countries of the world to develop their own definitions of multicultural education, within the general boundaries outlined above, to fit their specific needs, rather than imposing a universal structure to implement multicultural education. Thus, everyone involved must play an active role in implementing multicultural education. Promoting diversity means acknowledging diversity, incorporating diversity into all levels, and demonstrating pride in cultural pluralism, along with a sincere belief that diversity is desirable.

\section{IMPLICATIONS FOR SCIENCE EDUCATION IN AFRICA}

Realising the importance of science to development, Africa has, according to Ogunniyi (1996: 268), been eager to develop its scientific human power to attain a measure of self-reliance in the production of goods and services by expanding its educational facilities and setting up curriculum development and research centres, as well as developing policies on science education.

Many African countries' science educators, perhaps spurred on by reform efforts, such as those National Curriculum in the UK, the National Research Council's Standards and AAAS's Project 2061 in the USA, or UNESCO's Project 2000+, have reopened a global discussion about new directions in science education. Hence, they are currently rethinking their needs and priorities for school science in terms of "science for all." Multicultural education is typically a particular and unique approach to education. It aims to educate all learners in a multicultural community. This encompasses a comprehensive educational programme aimed at the optimal cognitive, affective and social development of all learners. Integrating multiculturalism into the science curriculum of African countries therefore might begin with what is called the additive process. Adding something "multicultural" to science teaching and learning is a good beginning process, but it must move toward the attainment of "multiculturalism." The following are some of the implications of multicultural science education for Africa:

1. Multicultural approaches to science education in Africa should aim at providing equitable opportunities, which includes an understanding of realities constructed by individuals from various cultural groups and how these realities can be reconstituted to include scientific reality. The content and methodology of a multicultural science curriculum, including resource materials, should be significant to students in school and at home. The curriculum should reflect diversity in our culture and society, help students to see the connection between their local and global environments, and think conscientiously and critically about their roles in these relationships. Multicultural science emphasizes dynamic inquiry and exploration, not static memorization of right and wrong answers. Science instruction should represent a variety of traditional and historical viewpoints - integrating literature, history and the arts. By presenting science as an ongoing, creative story with many parts, students will see their own cultural experiences reflected in the lesson.

Jegede (1995, p.124) recommended an approach to teaching science called conceptual eco-cultural paradigm, i.e. "a state in which the growth and development of an individual's perception of knowledge is drawn from the socio-cultural environment in which the learner lives and operates".

According to Jegede (1995), a conceptual eco-cultural paradigm consists of the following features:

- Generating information about the pupil's everyday environment to explain natural phenomena 
- Identifying and using the indigenous scientific and technological principles, theories, and concepts within the pupil's community

- Teaching the typical values of the indigenous community in relation to, and in the practice of, science and technology as human enterprises

2. Teachers should make border crossings explicit for pupils by promoting discourse so that pupils are: (a) talking in their own cultural interpretive framework, as well as in the framework of Western science without cultural violence, (b) immersed in either the pupils' indigenous life culture or the culture of science, and (c) cognizant about which culture they are talking in at any given time. Teachers should also use a variety of materials and resources and ensure that racially stereotyped material is either eliminated or addressed in an anti-racist fashion. Make sure that the oral narratives and heritage of the native community should become part of the school science experience.

3. Teachers should further ensure that the similarities and differences and the strengths and limitations of the two traditions should be articulated and explored during instruction. Teachers should also give attention to the language of science and help pupils who are accustomed to an oral tradition or who have language difficulties. According to Henderson \& Wellington (1998: 35), for many learners, the greatest barrier to learning science is language. The problem is that many other African countries have developed science curricula and content upon Western trends and teachers teach science mainly in English.

4. Teachers should provide a "multicultural view" of science and technology by drawing upon a variety of cultures when teaching science. Activities should be designed to help students recognize the likelihood of continual change, conflict, ambiguity, and increasing interdependence, while instruction should identify local approaches for achieving sustainability. Interactivity among pupils should encourage them to identify their own ideas and beliefs. Teaching strategies should emphasize solving science and technology problems, environmental problems, resource management, and sustainable societies' problems.

5. Teachers are largely responsible for what and how students learn. Therefore, the degree to which multicultural science education can be realized in African schools will depend largely upon the attitudes, knowledge, and behaviour of classroom teachers. As a starting point, science teachers should be familiar with their students' class distribution in terms of ethnic or cultural diversities, socio-economic background, interests, skills, and abilities. In a multicultural classroom, for example, diversity in cultural background ensures diversity in students' learning preferences and perspectives. Hence, the reality of cultural diversity should therefore be taken into account in lesson preparation, organizing effective instructional situations, motivating students, and managing classrooms.

6. Science teachers should also integrate discussions about science with history, morality, justice, equality, freedom, and spirituality. Teachers should provide a "multicultural view" of science and technology by drawing upon a variety of cultures when teaching science. Teaching strategies should emphasize solving science and technology problems, environmental problems, resource management, and sustainable societies' problems". Teaching materials, language used, written comments, work cards, assignments, and assessment should all be multi-culturally friendly. Teachers should substantiate and build on the validity of pupils' personally and culturally constructed ways of knowing by identifying and using the indigenous scientific and technological principles, theories, and concepts within the pupil's community and also use culturally sensitive instruction strategies The use of role models and constant examples of diverse career opportunities, especially featuring individuals whose gender or ethnic background is typically under represented in the field, should be encouraged. These "living proof" individuals can supply concrete images of success for the student as important role models.

7. Teachers should explore the content and epistemology of both scientific and indigenous knowledge systems. Such an exploration encourages pupils to identify any conflicts between the two systems and to feel secure with those conflicts. Substantiate and build on the validity of pupils' personally and culturally constructed ways of knowing. They should situate the science curriculum in the context of pupils' lives and cite examples of some relevant localized context for science instruction. "The oral narratives and heritage of the local native community should become part of the school science experience" and should therefore not be demeaned as being merely myth and legend. Teachers should be able to make references to the similarities, differences, strengths and limitations of our cultural heritage". For example, teachers should show pupils how concepts, such as heat, snow, and life cycles, are culture-laden in both traditions and 
also highlight, compare and explain the relationship between the world view of science and the world views of pupils' scientific preconceptions.

8. An effective teacher training programme for teaching science in a multicultural context should be structured around four fundamental types of learning that serve as pillars of knowledge throughout the individual's life. According to Delors, et al (1996), these are:

- Learning to know - acquiring instruments of understanding

- Learning to do - ability to act creatively in one's environment

- Learning to live together to cooperate and participate in all human activity

- Learning to be an essential component proceeding from prior three aspects

Thus, teacher-training programmes should reflect some of the following:

1. Positive self-identity-awareness, knowledge and understanding of one's own cultural heritage. These should be seen as necessary prerequisites for prospective teachers to respect and accept other cultural groups that are present in a multicultural classroom. Student teachers should be encouraged to understand other cultures as equal in order to foster mutual appreciation and acceptance among students in multicultural settings.

2. Teacher training courses should be designed in such areas as intercultural diversity in society, intercultural communication, and philosophy of multicultural education.

3. Besides being knowledgeable in the various subject areas, future science teachers should be trained to become competent in a variety of methodological techniques in other to adapt to different learning styles of students.

\section{CONCLUSION}

In conclusion, in many African countries today, the demand for secondary schools is far greater than the supply. The same pattern is true for primary and tertiary education. Consequently, an effective implementation of multicultural education in Africa should incorporate the following:

1. There should be a total school reform.

2. Schools should cater for all students in all grades and subjects.

3. The curriculum should involve acquiring knowledge, clarifying attitudes and values, and developing social actions and skills about ethnic and cultural pluralism.

4. Teaching should include recognizing, accepting, and celebrating diversity as a fundamental fact and salient feature in human life.

These changes can provide a modest start toward identifying the teaching and learning of science from this new perspective, in which learners attempt to transcend the borders of the culture of science and the culture of the learner's environment.

Today, with the multicultural realities of many of the world's classrooms, whether in Africa, Asia, or South America where indigenous pupils form part of the predominant culture - or in other parts of the world, such as Canada, the USA, Australia, and Europe where the minority of indigenous populations are made to function within the dominant Western culture, no nation should ignore the development of a science-for-all curriculum. It is evident from the literature that pupils experience at least three types of culture when they study science. There is the culture in a formal Western type educational setting, the culture of school science, and the culture of their life. To make meaning out of their experiences in science classrooms, pupils need to negotiate a cultural transition from their life into the world of school science. The ease or difficulty with which pupils make the transition (that is, the ease or difficulty with which they cross cultural borders) will determine their understanding of the subject. Science education must be culture sensitive for it to serve the emerging global community. There should be plenty of opportunities in the science curriculum for a wide range of information from non-WMS, "local"/"indigenous"/traditional"/"ethnic" understandings of nature and for challenges to WMS made from the perspectives of those alternative understandings. 


\section{AUTHOR INFORMATION}

Dr. Ayodele .O. Ogunleye is a teacher and science educator by profession. He is currently a Senior Lecturer in Science Education at the Faculty of Education, University of Lagos, Nigeria. He obtained M.Sc in Theoretical Physics, M. Ed in Science Education, M. Sc in Computing and IT and Ph.D. in Science Education. In addition, he earned a Diploma in Science Education from Chelsea College of Science and Technology, University of London. He was a Visiting Academic to the Institute of Education, University of London.

\section{REFERENCES}

1. AAAS. (1989). Project 2061: Science for all Americans. Washington, DC: American Association for the Advancement of Science.

2. Adams, H. H. I. (1990). African and African-American contributions to science and technology. Portland, OR: Multnomah School District, Portland Public Schools.

3. Aikenhead, G.S. (1994). Consequences to learning science through STS: A research perspective. In J. Solomon \& G. Aikenhead (Eds.), STS education: International perspectives on reform. New York: Teachers College Press, pp. 169-186.

4. Aikenhead, G.S. (1996). Science education: Border crossing into the subculture of science. Studies in Science Education, 27, 1-52.

5. Aikenhead, G.S., \& Jegede, O. J. (1999). Cross-cultural science education: A cognitive explanation of a cultural phenomenon. Journal of Research in Science Teaching, 36(3).

6. Arvizu, S. F. (1994). Building bridges for the future: Anthropological contributions to diversity and classroom practices. In: R. A. De Villar, C. J. Faltis \& J.P. Cummis (eds). Cultural diversity in schools: From rhetoric to practice. Albany: State Unversity of New York Press.

7. Atwater, M.M. \& Riley, J.P. (1993). Multicultural science education: Perspectives, definitions, and research agenda. Science Education, 77(6), 661-668.

8. Atwater, M. .M. 1996. Social Constructivism: Infusion into the Multicultural Science Education Research Agenda. Journal of Research in Science Teaching. Vol. 33, No. 8, pp.821-837edition.

9. Barba, R.H. (1993). A study of culturally syntonic variables in the bilingual/bicultural science classroom. Journal of Research in Science Teaching, 30(9), 1053-1071.

10. Banks, J. A. (1993) Goals of multicultural education. In: J. A Banks \& C.A. McGee Banks (eds). Multicultural education: Characteristics and goals. Boston: Ally \& Bacon.

11. Banks, J. A. (1994) An introduction to multicultural education. Boston: Allyn \& Bacon.

12. Banks, J. A. (1997b). Multicultural education: Characteristics goals. In J. A. Banks and C. A. M. Banks (Eds.), Multicultural education: Issues and perspectives (3rd ed., pp.385-407). Boston: Allyn and Bacon.

13. Banks, J.A. (1999) An introduction to multicultural education. $2^{\text {nd }}$ edn. Boston: Allyn \& Bacon.

14. Barba, R. H. (1995). Science in the multicultural classroom: A guide to teaching and learning. Needham Heights, MA 02194: Allyn and Bacon.

15. Basalla, G. (1967). The spread of western science. Science, 156, 611-622.

16. Behrens, C. A. (1989). The scientific basis for Shipibo soil classification and land use: changes in soil-plant associations with cash cropping. American Anthropologist, 91(1), 83-100.

17. Bernnett, C. I. (1986) Comprehensive multicultural education: Theory and practice. Boston: Allyn \& Bacon.

18. Bernnett, C. I. (1990) Comprehensive multicultural education: Theory and practice. $2^{\text {nd }}$ edn. Boston: Allyn \& Bacon.

19. Cobern, W. W. (1991). World view theory and science education research, NARST Monograph No. 3. Manhattan, KS: National Association for Research in Science Teaching.Cobern, W. W. (1995a). Belief and knowledge: Unnecessary conflict in the science classroom. In F. Finley (editor), Proceedings of the History and Philosophy of Science and Science Teaching. Minneapolis, MN: HPSST.

20. Cobern, W. W. (1995b). Science education as an exercise in foreign affairs. Science \& Education, 4(3), 287-302.

21. Coburn, W. W. \& Loving, C. C.(2001). Defining 'science' in a multicultural world: Implications for science education. Science Education, 85(1), 50-67 
22. Cummins, J.P. (1980). The language and culture issue in the education of minority language children. Interchange, 10(4), 72-88.

23. Delors, J. et al. (1996) Learning: the treasure within, Paris, UNESCO Hodson, D. (1993). In search of a rationale for multicultural science education. Science Education, 77(6), 685-711.

24. Driver, R. Leach, J., Millar, R, \& Scott, P. (1996). Young people's images of science. Buckingham, GB: Open University Press

25. Gay, G (1994) A Synthesis of Scholarship in Multicultural Education. Retrived from http://www.ncrel.org/sdrs/areas/issues/educatrs/leadership

26. Hanley, M.S. The scope of multicultural education. Retrived from http://www.newhorizons

27. Henderson, J. \& Wellington, J. 1998. Lowering the language barrier in learning and teaching science. School Science Review, 79(288) (pp 35-46)

28. Hodson, D. (1993). In search of a rationale for multicultural science education. Science Education, 77 (6), 685-711.

29. Hodson, D. (1993). In search of a rationale for multicultural science education. Science Education, 77 (6), 685-711.

30. Jegede, O. (1995). Collateral learning and the eco-cultural paradigm in science and mathematics education in Africa. Studies in Science Education, 25, 97-137.

31. Jegede, O. (1997). School science and the development of scientific culture: A review of contemporary science education in Africa. International Journal of Science Education, 19, 1-20.

32. Jegede, O.J., \& Okebukola, P.A. (1991). The effect of instruction on socio-cultural belief hindering the learning of science. Journal of Research in Science Teaching, 28, 275-285.

33. Kawagley, O. (1995). A Yupiaq worldview. Prospect Heights, IL: Waveland Press.

34. Kawagley, A. O., Norris-Tull, D., \& Norris-Tull, R. A. (1998). The indigenous worldview of Yupiaq culture: Its scientific nature and relevance to the practice and teaching of science. Journal of Research in Science Teaching, 35(2), 133-144.

35. Krugly-Smolska, E. (1997). Science education in an evolving multicultural education. In K. McLeod (Ed.), Multicultural education: The challenges and the future. Winnipeg: Canadian Association of Second Language Teachers.

36. Ladriere, J. (1977). The challenge presented to cultures by science and technology. Paris, France: UNESCO.

37. Lyotard, J. F. (1995). Toward the postmodern. Atlantic Highlands, NJ: Humanities Press.

38. Matthews, M. R. (1994). Science teaching: The role of history and philosophy of science. New York: Routledge.

39. National Academy of Sciences. (1984). Science and creationism: a view from the National Academy of Sciences. Washington, DC: National Academy of Sciences.

40. National Research Council. 1996. National Science Education Standards.

41. Washington: D

42. Ogawa, M. (1995). Science education in a multiscience perspective. Science Education, 79(5), $583-593$.

43. Okebukola, P.A.O. \& Jegede, O. J. (1990). Eco-cultural influences upon students' concept attainment in science. Journal of Research in Science Teaching, 27, 661-669.

44. Ogunniyi, M B 1996. Science, technology and mathematics:the problem of developing critical human capital in Africa. International Journal of Science Education. Vol. 18, No. 3, 267-284.

45. Ogunniyi, M.B., Jegede, O.J., Ogawa, M., Yandila, C.D., \& Oladele, F.K. (1995). Nature of worldview presuppositions among science teachers in Botswana, Indonesia, Japan, Nigeria, and the Philippines. Journal of Research in Science Teaching, 32(8), 817-831.

46. Ovando, C. J. \& Colliier, V.P. (1998) Billingual and ESL classrooms: Teaching in multicultural contexts. $2^{\text {nd }}$ edn. USA: McGraw- Hill Companies, Inc

47. Overton, W. R. (1983). The decision in McClean v. Arkansas Board of Education. Society, 20(2), 3-12.

48. Poole, M. (1995) Beliefs and values in science education. Buckingham:Open University Press.

49. Pomeroy, D. (1994). Science education and cultural diversity: Mapping the field. Studies in Science Education, 24, (49-73).

50. Reiss, M. J. (1993) Science Education for a Pluralistic Society. Buckingham: Open University Press.

51. Siegel, H. (1997) Science education: Multicultural and universal. Interchange, 28(2/3), 97-108. 
52. Snively, G., \& Corsiglia, J. (1998). Rediscovering indigenous science: Implications for science education. Paper presented at the National Association for Research in Science Teaching San Diego, CA, April.

53. Stanley, W. B., \& Brickhouse, N. W. (1994). Multiculturalism, universalism, and science education. Science Education, 78(4), 387-398.

54. Spindler, G. (1987). Education and cultural process: Anthropological approaches (2nd Ed.). Prospect Heights, IL: Wavelan Ezeabasili, Nwankwo. (1977). African Science Myth or Reality. New York, New York: Vantage Press d Press

55. Stanley, W.B., \& Brickhouse, N.W. (1995). Science education without foundations: A response to Loving. Science Education, 79, 349-354.

56. UNESCO. (1994). The project 2000+ declaration: The way forward. Paris: UNESCO

57. Van Sertima, Ivan. (1984). The Lost Sciences of Africa: An Overview. Ed. Ivan Van Sertima. New Brunswick (U.S.A.): Transaction Books. 7-26. 
NOTES 